\title{
An analysis of the influences of individual optimism, risk taking and self-confidence on professional accounting judgment
}

\author{
Victoria Bogdana, 1, I oana Teodora Meştera ${ }^{a}$ Dana Gherai ${ }^{a}$ and \\ Carmen Mihaela Scorțea \\ a University of Oradea, Romania
}

\begin{abstract}
A bstract: Chaotic dynamics of today's global business environment exert a tremendous pressure on professionals accounting judgment performance. A survey was mailed to Romanian professional accountants to examine their perception on accounting judgments and decisions. The results based on 531 valid responses indicate that professionals considered that a judgment in accounting is influenced by the responsibility of the accountant in preparing the financial statements according to the regulatory financial reporting framework. Also, they think that an adequate accounting judgment is best characterized by: "logical, consistent and substantiated", characteristics. Exploring statistical differences between accountants, grouped by age, gender, as well as years of practice, we found that younger investigated accountants are more optimistic that the ones over 45 . We have used Chi-Square test and Pearson's correlation coefficient and showed that there is a correlation between accountants' propensity towards optimism and their perception regarding the need of a theoretical framework of JDM, and between accountants' propensity towards risk and their choice regarding the aspects that influence accounting judgment. Also, accountants' self-confidence is in direct correlation with their opinion regarding the aspects that influence JDM in accounting, but there is no statistical correlation between accountants' propensity towards optimism and their choice regarding the aspects that influence accounting judgment Our results showed that is on interest to further investigate these correlations to identify new ways to improve JDM in accounting. The role of
\end{abstract}

\footnotetext{
${ }^{1}$ Corresponding author: Victoria Bogdan, University of Oradea, Faculty of Economics, str. Universitătii nr. 1, Oradea, 410089, Romania, email address:

victoria.bogdan10@gmail.com, vbogdan@uoradea.ro
} 
professional accountant is shaped by the pressure of several external factors that al so mark their behavior, hence, accountants are not robots, are humans.

Keywords: professional accountants, judgment and decision making, optimism, risk taking, self-confidence

J E L codes: M41, A14, Z13

\section{Introduction}

Given that the accounting standards offer mainly general guidance regarding preparation of financial statements, accounting professionals are found many times in situations requiring specialized skills, use of cognitive skills and exercise professional judgment (Brown et al., 1993), as the financial reports are the end of the product of numerous judgments and decisions (Hronsky \& Houghton, 2001). J udgment and decision-making in accounting is part of the psychological research area "Behavioral Decision Theory", which expl ores how the accountants make use of these skills - judgment and decision (Trotman, 1998).

The subject of judgment and decision-making in accounting, we found treated in literature since the twentieth century, when Mapp (1937) supports the idea that "factual information and accuracy in its procurement are essential, but its value is submerged unless with it is synchronized the development and training of the judgment". Later, in 1987 Treadway Commission emphasizes that "bona fide differences of opinion arise in financial reporting, especially if novel or complex transactions are involved. Generally accepted accounting principles may not al ways be clear on the appropriate accounting treatment and the company and its independent public accountant must use judgment in making a decision" (Treadway Commission, 1987). Although, we are in a time when research is highest in all areas, we support the idea that the accounting is very different from other areas, even from the audit because significant difference in various problems or analysis appear, or even in accounting judgment (Mason \& Gibbins, 1991).

In terms of accounting professionals, constantly subjected to pressure in order to make the best decisions, "accounting professionals, in general routinely think about actions, situations, objects, persons, or events outside the realm of their direct experience. That is, they think about the future or the past distant locations rather than proximate locations, other individuals" perceptions or experiences, or hypothetical events rather than actual events. They also make plans, render judgments, and make choices based upon, or influenced by those thoughts (Weisner, 2015). Chand and Patel (2011), in their research analyzed the period 
between 1972 and 2010, where in the five top-tier accounting journals, they made review of what have been published on accounting judgment and decision making. The review of the studies propose that judgment and decision making in accounting has some basic points: "(i) to identify the extents of similarity in the meanings of key accounting concepts held by various parties involved in the preparations and use of financial reports, ( ii) to describe how professional accountants interpret and apply accounting standards, in particular examining the ambiguity in the interpretation of uncertainty expressions, (iii) to identify the influence of other factors, including national and linguistic culture, on the interpretation and application of accounting standards, and (iv) to provide some insight into the theoretical and conceptual issues in accounting judgment and decision-making research".

The present study is based on a survey of Romanian professional accountants' opinion on judgment and decision making in accounting and is part of the studies that analyze the behavior of professional accountants. Taking into account the review of previous work on the topic we have set up research questions and elaborated hypotheses. We consider our endeavor adds value to the existing behavioral accounting research by questioning and investigating some potential correlation between individual traits, like: optimism, risk taking and selfconfidence and judgment and decision making in accounting. Our work is organized as follows: a brief introduction on behavioral accounting research and the first studies conducted on judgment and decision making in accounting announcing our intentions of research, prior research on the topic highlighting several studies related to accounting judgments, estimates and decision making, the methodology and sample selection process, descriptive statistics of the interested received responses from professional accountants, research questions and hypotheses based on the analysis of similar studies, the section of discussion of obtained results from the statistical testing of the work hypotheses and in the last section of the paper we have outlined the main findings, limits of our study and potential for future works on the topic.

\section{Previous research conducted on judgment, decision making and accounting professionals behavior}

Accounting is not an exact science, because getting relevant information is necessary to carry out the reasoning for each case (Istrate, 2004). Given this, becomes imperative, at a time when the truth is not only one, to investigate perceptions of professional accountants on accounting judgment and decision making. Reporting to timing, the 50is, when in judgment and decision making (JDM) prevailed mathematical models, now the reviews are structured by task categories, with section headings such as "preferences," "beliefs," and "decisions 
under risk and uncertainty" (Payne et al., 1992), and "risky choice," "intertemporal choice," and "social decisions" (Loewenstein et al., 2007).

As far as the notion perception is concerned, Solomon and Trotman (2003), noticed that judgments refer to "subjective assessments made as a prel ude to taking action" and decision mean "action that people take to perform some task or resolve some problem". Thus, investigating perceptions of professional accountants on accounting judgment and decision making has shown that judgment of professional accountants is not made in a vacuum and that a number of factors, like culture, level of education, experience, accounting firm affiliations, influence the accountants when making professional judgment (Libby \& Luft, 1993; Fraser \& Hatherly, 2003).

Chand and Patel (2011) found in the five top-tier accounting journals only 17 papers for the period 1972-2010, that fall within the domain of accounting judgment research. There are studies that provide some insight into the theoretical and conceptual issues in accounting judgment and decision making research (Belkaoui, 1980; Gibbins, 1984; Emby \& Gibbins, 1988; Brown et al., 1993; Hornsky \& Houghton, 2001; Doupnik \& Richter, 2003; Clor-Proell \& Nelson, 2007). Barcellos et al. (2016) conducted an exploratory analysis on Brazilian professional accountants; their cognitive reflection abilities were measured through Frederick's (2005) cognitive reflection test (CRT). The results reveal ed that male Brazilian accountants tend to be more reflective than their female counterparts and also, that professional accountants tend to become less reflective and more impulsive, as they age. Patel (2006), empirically examined through a survey questionnai re administered to a sample of senior professional accountants from Big Five accounting firms, the cultural influences on professional judgment of Australian, Indian and Chinese Malaysian accountants in relation to auditor-client conflict resolution, and whistle-bl owing as an internal control mechanism

Pate's (2006) results showed that Australian professional accountants are less likely to resolve audit conflicts by acceding to dients than Indian and Chinese Malaysian professional accountants, and are also less accepting of resolving audit conflicts in this way. Furthermore, Australian professional accountants are more likely to engage in whistle-blowing as an internal control mechanism than Indian and Chinese Malaysian professional accountants, and are also more accepting of doing so. The empirical study conducted on 251 professional accountants employed in Hong Kong firms, by Lui et al. (2001), examined interrole conflict influence on job satisfaction and propensity to leave. The obtained results from hierarchical regression analysis reveal ed that interrole conflict was associated with low job satisfaction and high propensity to leave. Another study written by Shafer (2002), examined the effects of ethical pressure on management accountant's perception of organizational-professional conflict, and related work outcomes. In 
order to asses Certified Management Accountants perception on the relevant variables a survey was mailed to a random sample of professionals and the obtained results indicated that ethical pressure was associated with higher levels of perceived organizational-professional conflict and also, higher levels of conflict were associated with lower levels of organizational commitment and job satisfaction. While, results of Patten's (1990) survey on lower level accounting professionals indicate that accountants have a higher perception of the importance of the heart traits (first identified by Maccoby) that have been associated with ethical inclinations than both managers and business students previously surveyed.

As regard the studies conducted on Romanian professional accountants' behavior, we mention that in 1999 and 2005 the attitude towards flexibility of a number of Romanian accountants were tested (Olimid \& Calu, 2010) and the authors observed that, over time, accountants' attitude moved to less uniformity. In another train of thoughts, Mustata et al. (2011) showed the sociological-psychological environment of accountants and their everyday problems and considered that Herzberg's theory can identify and explain reasonably well the motivational factors of today's Romanian accounting professionals. Albu et al. (2011a) are of the opinion that after a 50-year communist period and 20 years of continuous reforms as a background, the Romanian accountant is forced by the business environment to expand its roles, transforming more and more into a consultant or business analyst; the transformation being accompanied by a special emphasis on personal and environment-related competencies, leading to an improvement of CSR practices. Also, Albu et al. (2011a) revealed that future development of the Romanian profession is needed and the Romanian accounting professional bodies, CECCAR and CAFR, have to commit to increase the orientation or Romanian accountants towards CSR, as other professional bodies do at the international level.

Other studies analyzed the historical evolution of accounting and the change in the accounting profession in Romania (Albu et al., 2010; Albu et al., 2011b) or the ethical behavior of the accountants (Usurelu et al., 2010).

\section{R esearch methodology and sample selection process}

\subsection{M ethodology}

We carried out this study based on the results of previous research (Bogdan et al., 2016; Bogdan et al., 2015a; Bogdan et al., 2015b) which had as central objective testing the correlations between various endogenous psychological variables or certain personality traits and the perception of MA students in accounting and finance regarding the accounting professional judgment. Our study is among questionnaire-based studies conducted by the investigation of professional 
accountants on their cognitive abilities, their specialized and transversal competences or professional judgment. The main objective of our study is to investigate the perception of professional accountants on professional judgment and accounting decision making. In this view, the research instrument used was the questionnaire that was sent to professional accountants. In this endeavor we have included in the category of professional accountants the people who operate mainly in accounting and who are chartered accountants or certified accountants certified by the professional body CECCAR.

The questionnai re contains 43 questions out of which:

$>7$ questions aim at general information on education and professional qualification, experience, the organization of business and professional income, age and gender of respondents;

> 20 questions investigating the professional judgment and accounting options, as follows: 3 questions aim at the perception of professional accountants of the influences and motivations in exercising the professional judgment and the interest in selecting accounting policies, 6 questions are related to the theoretical framework of professional accounting judgment (KPMG, 2011), 4 questions seek the respondents' perception on the attributes of professional accounting judgment and the behavior of professionals to its characteristics, a question envisages the professional judgment exercised in order to award an accounting treatment, 4 questions are intended to interview the respondents in terms of the relationship between the time factor, customer satisfaction, the expectations of managers and the professional accounting judgment and 2 questions target the link between the professional reasoning and costing;

$>16$ questions are considering testing some of the personality traits of the respondents such as their ability to make decisions autonomously, the optimism of people, their tendency to assume risk, their creativity, the fact that they are self-confident and convincing people, and their resistance to stress. The last 4 questions are noticeable in the questionnaire since they took into account the testing of the personality traits of respondents by projective techniques, using the association method (Bogdan et al., 2016; Balaciu et al., 2014).

Of the 43 questions a number of 6 questions are open, mostly being closed questions where was asked to tick one or more responses as appropriate. The Likert scale with 5 response options has been used. The period of application of the questionnaire was October 2016 - January 2017. It was administered for completion by meeting, face to face, the professional accountants at the monthly meetings that took place at the branch. To be completed by as many professional 
accountants in the country the questionnaire was posted online. The link where the questionnaire could be accessed for completion was mailed with an accompanying message to all the professional accountants contained in the 2016 CECCAR, table, published in the Official Gazette no. 417 bis / 02.06.2016, Part I. Obviously, messages were sent to request the completion of the questionnaire by professional s that had valid email addresses. The sample selection process of the professional accountants is presented bellow. The statistical processing of the responses was carried out using SPSS v.20. We have used Cronbach's al pha, in order to check the internal consistency of our questionnaire, the value of the statistic being 0.83 , which confirms its reliability. For the validation of our research hypothesis, we have used the Chi-Square test, which is a non-parametric test used for the analysis of the existence of a correlation between two variables (numerical or alpha numerical), as well as the Pearson's correlation coefficient, in order to evaluate its direction and intensity.

\subsection{Sample selection process}

From the 2016 CECCAR Table published in the Official Gazette no 417 bis / 02.06.2016, Part I, we selected the email addresses of the chartered accountants, certified accountants, natural persons and the email addresses of auditing and consulting companies, for all the counties of the country. Botoşani and Brăila counties were excluded from the sample because they had not published the email addresses of the CECCAR either in the Official Gazette or on their own web pages. The mail addresses were collected for the board members of CECCAR both in the picture published in the Official Gazette and on the public web pages of CECCAR organizations subsidiaries. About $20 \%$ of the emails sent were invalid because of incorrect or inexistent email addresses and the average response rate per county was between 7 and $10 \%$. At the end of the period of administration of the questionnaire a number of 531 val id responses were obtained.

\section{Descriptive statistics}

Most of the professional accountant respondents, around $44 \%$, are university graduates with bachelor degree in economics, followed by those with higher economic education, bachelor and master, around 33\%. And, as it can be seen in the diagram below, regarding the professional profile of the respondents, most of them are chartered accountants ( $54 \%)$, followed by those qualifying as chartered accountants and auditors, the least being the liquidators (6.3\%). 


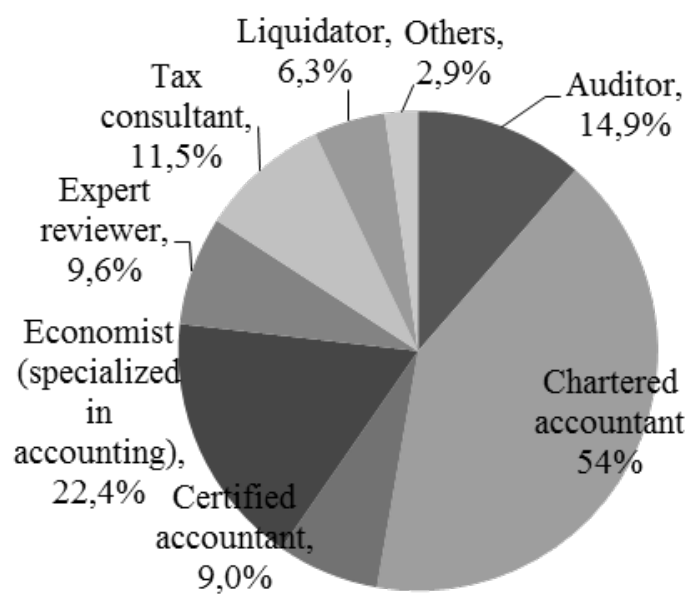

Figure 1. The professional profile of respondents

In terms of practical professional experience in accounting, $76.8 \%$ said they had over 10 years of experience in accounting, only $1.1 \%$ of them not having at all or being inactive. And regarding the organization of work for accounting services rendered, $40.9 \%$ of the total, are freelancers without employees, a close share (38.6\%) having those who are the employees of an entity. An interesting situation is that of the responses on the annual income obtained from accounting services rendered. As seen in the chart below, most of the respondents obtained from accounting services rendered, annual income between 10,000 lej and 25,000 lei, and 25,000 lei and 50,000 lei, respectively.

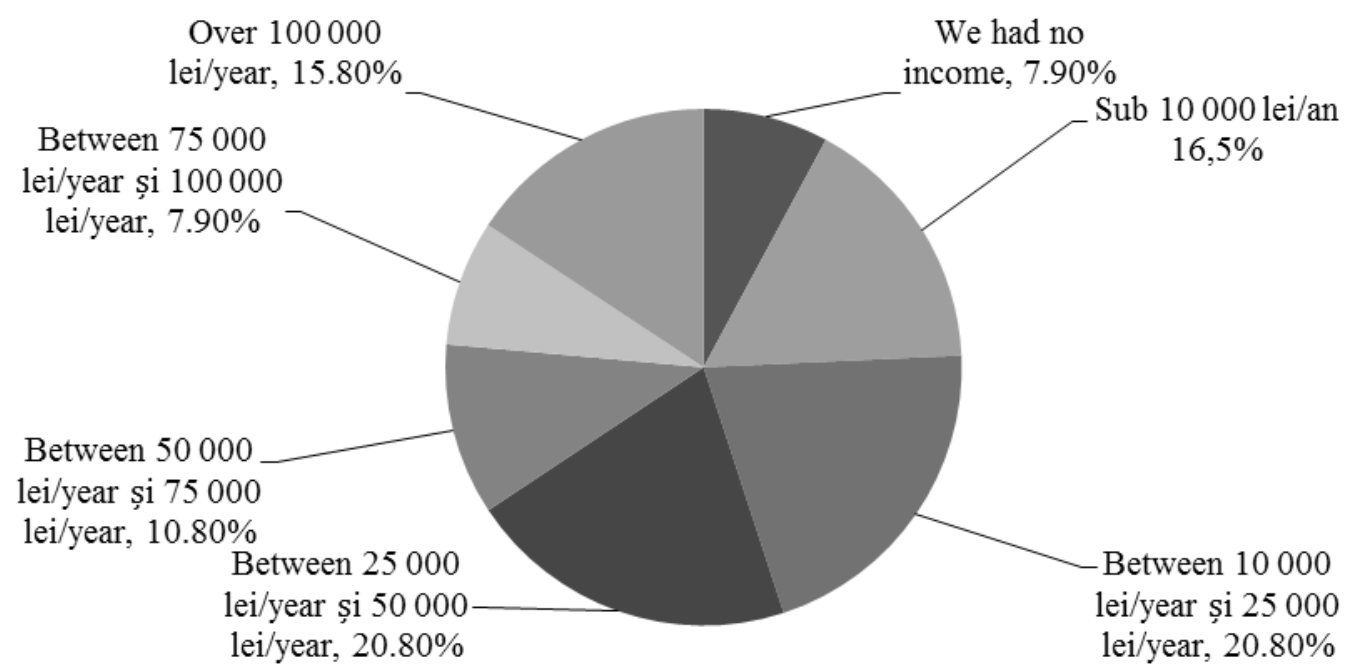

Figure 2. Distribution of income obtained from services provided by investigated professional accountants 
$38 \%$ of the professional accountants investigated are over 50 years of age, 30.5\% are aged between 35 and 45 years and those aged 23 to 30 have the smal lest share. A surprising situation for us is the distribution of respondents by gender, thus more than three quarters of the respondents are female persons (76.2\%). On the main aspects that influence the exercise of professional accounting judgment when seeking the election of an accounting treatment for accounting the economic and/or financial events and transactions, the largest share of the respondents consider that the responsibility of the accountant to prepare financial statements in line with the economic reality and the provisions of the regulatory framework for accounting and financial reporting are relevant, while the expectations of owners to obtain dividends as favorable as possible exercise the smal lest influence on the accounting professional judgment.

Table 1. Factors that influence the professional accounting judgment in the perception of investigated professionals

\begin{tabular}{|c|c|c|c|c|c|}
\hline \multicolumn{6}{|l|}{$\begin{array}{l}\text { Respondent's opinion } \\
\text { regarding the item }\end{array}$} \\
\hline $\begin{array}{l}\text { Factors } \\
\text { that influence the } \\
\text { professional accounting } \\
\text { judgment in the perception of } \\
\text { investigated professionals }\end{array}$ & $\begin{array}{l}\text { Strongly } \\
\text { agree }\end{array}$ & Agree & Undecided & Disagree & $\begin{array}{l}\text { Strongly } \\
\text { disagree }\end{array}$ \\
\hline $\begin{array}{l}\text { The provisions of the regulatory } \\
\text { accounting and financial reporting } \\
\text { framework }\end{array}$ & $60,22 \%$ & $39,05 \%$ & $0,73 \%$ & 0 & 0 \\
\hline $\begin{array}{l}\text { Generally accepted accounting } \\
\text { principles }\end{array}$ & $55,21 \%$ & $43,76 \%$ & $1,02 \%$ & 0 & 0 \\
\hline $\begin{array}{l}\text { The expectations of owners in terms } \\
\text { of obtaining dividends }\end{array}$ & $9,25 \%$ & $29,25 \%$ & $28,39 \%$ & $18,49 \%$ & $14,62 \%$ \\
\hline $\begin{array}{l}\text { The expectations of owners in terms } \\
\text { of the entity's financial position and } \\
\text { performance }\end{array}$ & $12,10 \%$ & $40,17 \%$ & $24,41 \%$ & $14,04 \%$ & $9,29 \%$ \\
\hline $\begin{array}{l}\text { The provisions of the manual of } \\
\text { accounting policies and procedures } \\
\text { of the entity }\end{array}$ & $39,88 \%$ & $52,69 \%$ & $5,79 \%$ & $1,03 \%$ & $0,62 \%$ \\
\hline Accountant's personality & $21,46 \%$ & $27,47 \%$ & $25,32 \%$ & $14,81 \%$ & $10,94 \%$ \\
\hline $\begin{array}{l}\text { Accountant's culture, education and } \\
\text { professional experience }\end{array}$ & $47,30 \%$ & $43,78 \%$ & $5,81 \%$ & $1,66 \%$ & $1,45 \%$ \\
\hline $\begin{array}{l}\text { Code of ethics and professional } \\
\text { deontology }\end{array}$ & $44,81 \%$ & $46,06 \%$ & $7,47 \%$ & $1,04 \%$ & $0,62 \%$ \\
\hline $\begin{array}{l}\text { Accountant's communication skills } \\
\text { with stakeholders }\end{array}$ & $19,96 \%$ & $45,49 \%$ & $25,75 \%$ & $5,58 \%$ & $3,22 \%$ \\
\hline $\begin{array}{l}\text { Accountant's responsibility in } \\
\text { preparing financial statements }\end{array}$ & $63,62 \%$ & $33,74 \%$ & $2,64 \%$ & 0 & 0 \\
\hline
\end{tabular}

Most of the respondents ( $64 \%$ of them) totally agree with the fact that professional accounting judgment may only be exercised after the information on economic/financial event or transaction has been collected and analyzed. Almost 
half of the interviewed subjects (49\% of them) believe that the professional accounting judgment can be exercised only in the context of a conceptual applicable accounting framework, of accounting standards or regulations and other accounting guides. Almost half of the interviewed subjects (48\%) agree with the fact that the professional accounting judgment may be exercised only after a process of appropriate logical judgments, a figure close to these being strongly in agreement with this statement and almost two thirds of the respondents strongly agree with the fact that the professional accounting judgment should be properly documented. Nearly half of the subjects, the share of $47 \%$, consider that the choice of an accounting treatment following the exercise of a professional accounting judgment will be done in consultation with the management of the entity, while more than half of the respondents strongly agree with the statement that adequate and quality professional accounting judgment affect the relevance of the financial accounting information. More than half of those surveyed (56\%) strongly agreed with the statement that the exercise of professional accounting judgment is a key skill for the accounting professionals, while less than half of those surveyed (48\%) agree with the statement that professional accountants must question the economic events / transactions to exercise a proper professional judgment. An interesting perspective was outlined in the analysis of responses to the question which concerned the most important characteristics of an adequate accounting reasoning. The respondents to this question were asked to choose and to number on a scale Likert 5, in terms of importance, 5 of the 8 characteristics mentioned. As seen in the chart below, according to the respondents, the adequate accounting judgment is characterized best by the following characteristics: "logical, consistent and substantiated", followed by "independent, without being influenced by the will of managers" and in the lowest proportion by "flexibility".

Table 2. Characteristics of an adequate professional accounting judgment in the opinion of investigated professionals

\begin{tabular}{|c|c|c|c|c|c|}
\hline $\begin{array}{l}\text { Respondent's opinion } \\
\text { regarding the item }\end{array}$ & & & & & \\
\hline $\begin{array}{l}\text { Characteristics of } \\
\text { an adequate professional } \\
\text { accounting judgment in the } \\
\text { opinion of investigated } \\
\text { professionals }\end{array}$ & $\begin{array}{l}\text { Very } \\
\text { important }\end{array}$ & Important & $\begin{array}{l}\text { Less } \\
\text { important }\end{array}$ & $\begin{array}{l}\text { The least } \\
\text { important }\end{array}$ & $\begin{array}{l}\text { Indifferent/ } \\
\text { Unsignificant }\end{array}$ \\
\hline $\begin{array}{l}\text { Logical, consistant and } \\
\text { documented }\end{array}$ & $66,53 \%$ & $21,43 \%$ & $5,92 \%$ & $2,65 \%$ & $3,47 \%$ \\
\hline Flexible & $16,25 \%$ & $44,69 \%$ & $19,69 \%$ & $9,38 \%$ & $10,00 \%$ \\
\hline $\begin{array}{l}\text { Precise, using only relevant } \\
\text { information }\end{array}$ & $38,52 \%$ & $40,37 \%$ & $10,90 \%$ & $5,80 \%$ & $4,41 \%$ \\
\hline $\begin{array}{l}\text { Accurate, not altered by } \\
\text { errors }\end{array}$ & $51,95 \%$ & $32,03 \%$ & $8,01 \%$ & $4,33 \%$ & $3,68 \%$ \\
\hline $\begin{array}{l}\text { Reasonable, estimating the } \\
\text { probabilities generated by } \\
\text { risks and uncertainties }\end{array}$ & $21,97 \%$ & $48,74 \%$ & $15,91 \%$ & $6,82 \%$ & $6,57 \%$ \\
\hline
\end{tabular}

Vol. 16, No. 3 


\begin{tabular}{|c|c|c|c|c|c|}
\hline $\begin{array}{l}\text { Respondent's opinion } \\
\text { regarding the item }\end{array}$ & & & & & \\
\hline $\begin{array}{l}\text { C haracteristics of } \\
\text { an adequate professional } \\
\text { accounting judgment in the } \\
\text { opinion of investigated } \\
\text { pr ofessionals }\end{array}$ & $\begin{array}{c}\text { Very } \\
\text { important }\end{array}$ & Important & $\begin{array}{l}\text { Less } \\
\text { important }\end{array}$ & $\begin{array}{l}\text { The least } \\
\text { important }\end{array}$ & $\begin{array}{l}\text { Indifferent/ } \\
\text { Unsignificant }\end{array}$ \\
\hline $\begin{array}{l}\text { Targeted, determining the } \\
\text { decision as a result of a } \\
\text { choice from several options }\end{array}$ & $19,35 \%$ & $45,54 \%$ & $15,77 \%$ & $11,01 \%$ & $8,33 \%$ \\
\hline $\begin{array}{l}\text { Independent, not influenced } \\
\text { by the managers' decision } \\
\text { Balanced, harmonizing the }\end{array}$ & $49,27 \%$ & $30,69 \%$ & $8,35 \%$ & $5,85 \%$ & $5,85 \%$ \\
\hline $\begin{array}{l}\text { experience with knowledge, } \\
\text { intuition and emotions }\end{array}$ & $40,40 \%$ & $30,81 \%$ & $9,60 \%$ & $9,34 \%$ & $9,85 \%$ \\
\hline
\end{tabular}

To the open question which related to the listing of the first words that come to the mind of the respondents when they hear the phrase professional accounting judgment, the analysis of responses indicates a multitude of options out of which the following can be distinguished, in order of preference of the respondents: fairness, logic, experience - professionalism or balance The analysis of responses to questions that test the main personality traits of the respondents shows that $75 \%$ of the respondents surveyed consider to a large or very large extent that, under conditions of uncertainty, their expectations are positive. This is confirmed by the result of responses to the question what they would do if they held a garden party and on the day of the event it would rain heavily, showing that two-thirds of the respondents felt they had bad luck and that the next party would be a success. Therefore, from the analysis and interpretation of the above responses we can recognize and identify a trend toward optimism of professional accountants interviewed in what concerns the perception of unforeseen or uncertain events. Further, being asked if they are willing to take a failure when they do something innovative, more than half of the respondents (53.9\%) say yes to a large extent and $21.6 \%$ to a very large extent and the fact that they usually have concerns that something unforeseen could ruin their plans, more than $60 \%$ of the respondents say that only slightly and only $25 \%$ say that to a high or very high extent. We can thus recognize from the interpretation of responses that there is a propensity of professional accountants investigated towards risk taking. The subjects were also interviewed on the ability to have confidence in themselves so that the results of the interpretation of results obtained indicate that $69.6 \%$ of the respondents believe that they are largely convincing people, and $21.1 \%$ to a very high extent and also, $63.7 \%$ of the respondents believe that they easily recognize their mistakes to a high extent and $29.8 \%$ to a very high extent. Therefore, we can identify a trend of professional accountants investigated towards self - confidence and the ability to persuade. 


\section{R esearch questions and hypotheses}

Gray (1988) using Hofstede's (1980) societal cultural patterns showed that the value systems or attitudes of accountants may be expected to be related to and derived from societal values with special reference to work related values. As a consequence, accounting values will, in turn, impact on accounting systems (Gray, 1988). Given those shown by us in previous studies conducted with reference to the professional accounting judgment (Bogdan et al., 2016; Bogdan, et al., 2015a; Bogdan et al., 2015b), we formulate the foll owing research questions:

1) What is the perception of professional accountants investigated on the need for a theoretical framework of professional accounting judgment?

2) Do the personality traits considered (optimism, risk and self-confidence) influence the choice of respondents in what concerns the choice of the main aspects that determine the exercise of an accounting judgment when seeking the allocation of an accounting treatment for economic and / or financial events or transactions?

3) Do the personality traits considered (optimism risk and self-confidence) influence the perception of professional accountants to investigate the need for a theoretical framework of professional accounting judgment?

To answer the above questions, we have developed the following research hypotheses, grouped in three analysis panels:

\subsection{Optimism and accounting professionals' judgment}

Conservatism versus optimism, as cultural dimension of accounting has been studied and investigated by many researchers from the impact on accounting measurement practices. As Gray (1988) emphasized conservatism versus optimism means a preference for a cautious approach to measurement so as to cope with the uncertainty of future events as opposed to a more optimistic, laissez-faire, risk taking approach. Optimism may be defined as a generalized expectancy for positive outcomes independent of the source of the outcomes (McKenna, 1993). According to Weinstein (1980), people believe that they are less at risk than their peers for many negative events and al so, the optimistic bias can be assessed either directly or indirectly (Weinstein \& Klein, 1996). In a meta-analysis of 27 independent samples Klein and Larsen (2002), investigated the relationship between optimistic bias and perceived control finding out that the greater control people perceive over future events, the greater their optimistic bias but this relationship was shaped by participants' nationality, education status and risk status. Bimberg (2011), observed that in the last decades psychologists, experimental economists and accountants have begun to examine the role of the decision maker's emotional state (affect) on the decision process. Thus, Chung et al. (2008) analyzed auditors' behavior making inventory valuation decisions and 
found that mood state affects the degree of conservatism in the audit mission. Hence, the author highl ighted that auditors in a positive mood are less conservative than those in a negative mood. We must understand and do not forget that special ists, either they economists, engi neers, accountants, judges, etc. before being specialists are humans. Humans do not act like robots. Lerner and Keltner (2000, 2001) reported that fearful individuals make more pessimistic estimates and more risk-averse choices, while anger leads individuals make more optimistic risk estimates and risk-seeking choices. Considering those shown above, we formulated thefollowing hypotheses:

H1: There is a correlation between the trend toward optimism of professional accountants and the option of the respondents on the main aspects that determine the exercise of the accounting judgment.

H2: There is a correlation between the tendency towards optimism of professional accountants and their perception towards the need for a theoretical framework of professional accounting judgment.

\subsection{Risk taking and accounting professionals judgment}

According to Kahneman (2011), the author who knows perhaps more than anyone else about the oddities of human assessment of risk is Paul Slovic. The same Kahneman (2001), identifies in Slovic's work studies both on ordinary citizens, led by emotion rather than by reason, easily influenced by unimportant details and having an inadequate sensitivity to the differences between the low probabilities and the negligible ones, and on the experts who are far superior in operations with figures and amounts. Slovic, quoted by Kahneman (2001), shows that the experts exhibit the many of the same biases as ordinary people, in attenuated forms, but often their assessments and their preferences for risk disagree with those of other people. The same Kahneman (2001) stresses the fact that Slovic, challenged the full control of experts on risk management policies and the idea that risk is objective. Risk does not exist outside of us, irrespective of our culture and mind, waiting to be measured; human beings have invented the concept of risk to help them understand and adjust to the uncertainties of life (Slovic, 2000).

Weber and J ohnson (2009) noted that psychophysical risk return models assume that perceptions of risk and return are psychological constructs that can vary between individuals and as a result of past experiences and decision content and context. Observed risk taking is the result of a long list of cognitive and affective evaluation and integration processes (Weber \& Johnson, 2009). An important premise is one of Miller's (1987) that business is inherently risky and all decisions in business involve risk. Masters and Deines (2011) focused on the examination of risk taking propensity of management accountants and whether gender and professional certification affects their tendency to take risk. In the opinion of Masters and Deines (2011) differences in risk taking propensity exist between CPAs and noncertified accountants because of the differences in their training and 
experience Helliar et al. (2002) examined through a large survey among accountants and managers the attitudes to risk by Scottish chartered accountants and considered whether their risk-taking attitudes are similar to or different from those of other business managers in the U.K. The results of Helliar et al. (2002) study showed that accountants and managers exhibit many of the biases that have been documented for executives in other countries: a focus on the framing of a decision, an emphasis on the magnitude of negative outcomes and an insensitivity to probability estimates. We share Weber and J ohnson's (2009) view regarding the study of risk taking propensity of management accountants, CPA's and non-CPA's, that identifying the differences will help the management clarify the type of controller needed in the firm's approach to taking risk and also it will assist accountants in understanding their role as a controller.

Considering of interest, in the light of the above, the inclination toward risk of professional accountants we have devel oped the foll owing assumptions:

H3: The propensity towards risk of the professional accountants investigated affect their option on the main aspects that determine the exercise of the accounting judgment

H4: The propensity towards risk of the professional accountants investigated is in an inverse correlation with the need for a theoretical framework of professional accounting judgment.

\subsection{Self-confidence and accounting professionals' judgment}

Siegel (2000) as a result of the interview conducted on management accountants in respect to the skills needed for entry level management accountant positions observed that several professionals mentioned the confidence factor. In professionals' view, schools could better prepare people for the work environment, teach student show to talk to people and not step on their feet. Siegel (2000) underlined that surveyed management accountants considered that one solution for professionals is to do things that generate self-confidence like getting a broader education or becoming involved in sports. On the other hand, J ones and Abraham (2008) noted that accounting practitioners are no longer merely required to undertake tasks such bookkeeping, data analysis or tax preparation, instead their role is extended to knowledge professionals with a greater emphasis on emotional intelligence. Thus, Jones and Abraham (2008) investigating the role of emotional intelligence in accounting education found out that academics who had been employed as practicing accountants had higher perceptions of the importance of particular roles undertaken and skills needed by graduates, which included personal skills likeself-confidence, self-belief and management proficiency.

An exploratory study made by Gul (1983) was interested in obtaining preliminary evidence on whether age, experience, cognitive styles influence accountants' decision confidence. Gul (1983) hypothesized that accountants who are relatively 
field dependent are likely to make decisions more confidently than their relatively more field dependent accountants, when provided with ambiguous type information. More accounting studies are concerned with analyzing overconfidence. As Russo and Schoemaker (1992) noted good decision making requires more than knowledge of facts, concepts and relationships but unfortunately we tend to have a deeply rooted overconfidence in our beliefs and judgments. Russo and Schoemaker (1992) considered that overconfidence has remained a hidden flaw in managerial decision making. There are several ways to define or to measure overconfidence and also overconfidence shows up in many different ways (Bar-Y osef \& Venezia, 2014). DellaVigna (2009) defined overconfidence as the overestimation of one's own performance in task requiring ability that includes the precision of one's own information. As Ifchner and Zarghamee (2014) observed, overconfidence is a systematic deviation from standard economic theory about beliefs. Barber and Odean (2001) showed that overconfidence has been identified among psychologists, physicians, nurses, investment bankers, engineers, entrepreneurs, lawyers, negociators and managers and showed that particularly in financial markets men are more overconfident than women. Empirical evidence of overconfidence's effect on economic decisions we found in Malmendier and Tate (2005), showing that overconfident CEOs make inferior corporate investments and Oyer \& Schaefer (2005), empirical investigating employees' overconfidence in order to analyze the company's policy on stock options for compensation. From the perspective of those shown in the above lines we proposed the hypothesis testing:

H5: Self-confidence of professional accountants interviewed positively influence their option on the main aspects that determine the exercise of the accounting judgment.

H6: Self-confidence of professional accountants interviewed directly influence their option on the need for a theoretical framework of professional accounting judgment.

\section{Discussion of results}

We have first investigated a potential statistical difference between accountants, grouped by gender, age as well as years of practice in what concerns optimism, risk taking and self-confidence. We have conducted a T-test for the difference between the means in each group, the value of the statistics being presented together with their corresponding probability of acceptance of the null hypothesis.

Table 3. Statistical difference analysis conducted on the investigated professional accountants

\begin{tabular}{ccccccc}
\hline & \multicolumn{2}{c}{ G ender } & \multicolumn{2}{c}{ Age } & \multicolumn{2}{c}{ Years of practice } \\
\hline & $\mathrm{F}$ & $\mathrm{M}$ & $25-45$ & Over 45 & \multicolumn{2}{c}{$\begin{array}{c}\text { Under 10 } \\
\text { Over 10 } \\
\text { yrs }\end{array}$} \\
$\begin{array}{c}\text { Optimism } \\
\text { average } \\
\text { coefficient }\end{array}$ & 3,639279 & 3,792373 & 3,782511 & 3,523636 & 3,601064 & 3,648010 \\
& & & & & &
\end{tabular}


An analysis of the influences of individual optimism, risk taking and self-confidence on professional accounting judgment

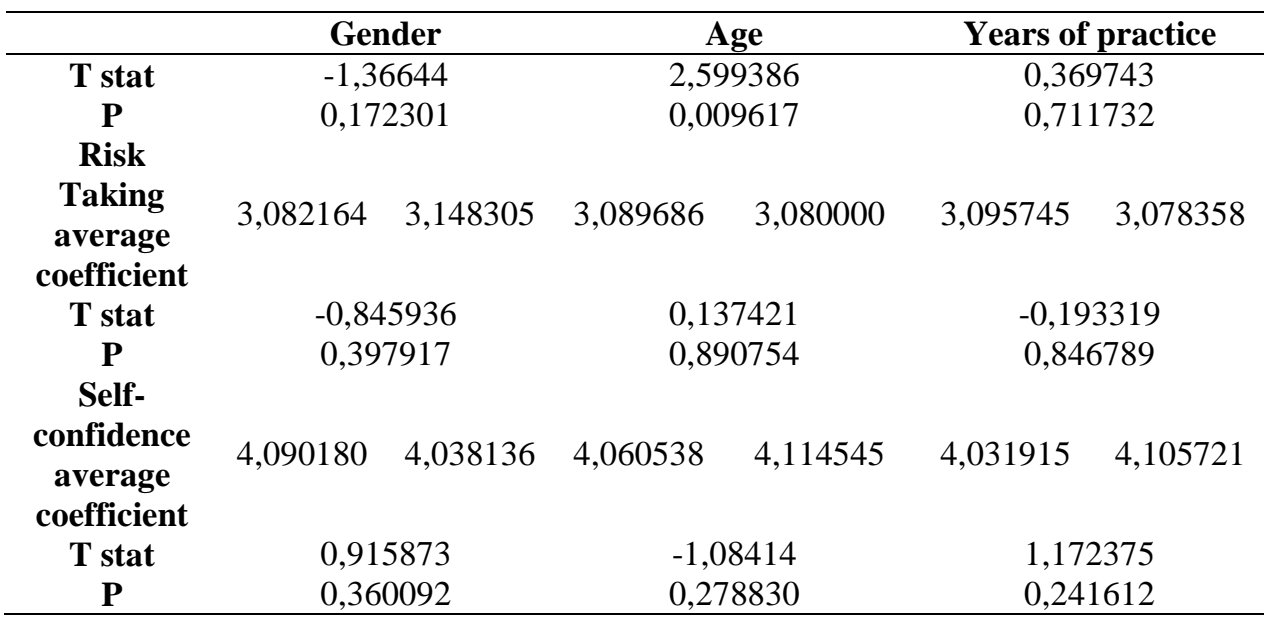

Our conclusion was that there is a statistical significant difference only in what regards the optimism of the accountants, grouped by age. The younger accountants are more optimistic that the ones over 45 . Further on, in this stage of our research each hypothesis was analyzed and interpreted, using specific statistic cal culations, qual itative appreciations and direct observations of data gathered.

H1: Professional accountants' propensity towards optimism is correlated to their choice regarding the main aspects that influence the professional accounting judgment.

For the val idation of this hypothesis we have analyzed the answers to the following questions: Q30. When in uncertainty, your expectations are usually positive? Q31. You planned an outdoor party but in the day the party should take place it pours cats and dogs. What do you think about it? as well as Q8. Which are the aspects that you believe to influence the professional accounting judgment when choosing an accounting treatment for economic and/or financial events and transactions? In order to investigate this research hypothesis, based on answers to questions Q30 and Q31, we have determined an average score for each subject, ranging from 1 to 5 , the highest val ue indicating a maximum propensity towards optimism A similar average score has been computed, using the answers to question 8, these scores ranging from 1 to 5 as well, the lowest value reflecting a total disagree with the particular aspects that influence the professional accounting judgment. The Chi square value associated to the distribution of the answers to the questions is 30.5, the value is higher than 0 , which indicates a correl ation between the accountants' propensity towards optimism and their choice regarding the main aspects that influence the professional accounting judgment. The value is not statistically significant as the critical value for a 5\% level of confidence and 24 degrees of freedom is 36.42 , higher than our cal culated value $\mathrm{H} 1$ is therefore not val idated. 
Our second assumption is:

H 2: There is a correlation between the accountants' propensity towards optimismand their perception regarding the need of a theoretical framework of professional accounting judgment

For the val idation of this hypothesis we have analyzed the answers to the following questions: Q30. When in uncertainty, your expectations are usually positive? Q31. You planned an outdoor party but in the day the party should take place it pours cats and dogs. What do you think about it? as well as Q11. Do you believe that the accounting professional judgment can be carried out only after all the information regarding the event or economic/financial transaction had been collected and analyzed? Q12. Do you believe that the accounting professional judgment can be carried out only in the presence of an applicable accounting conceptual framework for the accounting standards, regulations and other accounting guide books? Q13. Do you believe that the accounting professional judgment can be carried out only after a proper logical reasoning process? Q14. Do you believe that the accounting professional judgment should be adequately documented? In order to investigate this research hypothesis, based on questions Q30 and Q31, we have used the average scores computed previously, the highest value indicating a maximum propensity of towards optimism A similar average score has been computed, using the answers to questions 11, 12, 13 and 14, these scores ranging from 1 to 5 as well, a high value reflecting a strong agreement with the necessity of a theoretical framework of the accounting professional judgment The Chi square value associated to the distribution of the answers to the questions is 115.01, which indicates a correl ation between the answers in the sample. The value is statistically significant as the critical value for a $5 \%$ level of confidence and 90 degrees of freedom is 113.15, lower than our cal culated val ue. $\mathrm{H} 2$ is therefore val idated.

H3: Accountants' propensity towards risk influence their choice regarding the main aspects that influence the professional accounting judgment.

For the val idation of this hypothesis we have analyzed the answers to the following questions: Q32 Are you usually taking upon yourself the blame of a failure when trying to do something innovative?, Q33 Do you usually fear that something unpredictable could ruin the plans? as well as Q8. Which are the aspects that you believe to influence the professional accounting judgment when choosing an accounting treatment for economic and/or financial events and transactions?

We have computed average scores for the answers to questions 32 and 33 ranging from 1 to 5 - the higher the value, the higher the propensity towards risk. The Chi square value associated to the cross tabulation between the average values is 357.01 which indicates a strong correl ation between the answers in the sample. The value is statistically significant as the critical value for a $5 \%$ level of confidence 
and 266 degrees of freedom is 305.04, lower than our cal cul ated val ue. H3 research hypothesis is therefore validated.

H4: An inverse correlation between accountants' propensity towards risk and their perception regarding the need of theoretical framework in what concerns the accounting professional judgment can berecognized.

For the validation of this hypothesis we have anal yzed the answers to the following questions: Q32 Are you usually taking upon yourself the blame of a failure when trying to do something innovative?, Q33 Do you usually fear that something unpredictable could ruin the plans? as well as Q11. Do you believe that the accounting professional judgment can be carried out only after all the information regarding the event or economic/financial transaction had been collected and analyzed? Q12. Do you believe that the accounting professional judgment can be carried out only in the presence of an applicable accounting conceptual framework for the accounting standards, regulations and other accounting guide books? Q13. Do you believe that the accounting professional judgment can be carried out only after a proper logical reasoning process? Q14. Do you believe that accounting professional judgment should be adequately documented? The average scores for the answers to questions 32 and 33 were correl ated with the corresponding average scores for the answers to questions 11, 12, 13 and 14, the higher the values, the stronger the belief that there is a need of theoretical framework in what concerns the accounting professional judgment. The Pearson's correlation coefficient is equal to 0 , so there is absol utely no correlation between the answers to the 2 sets of average scores. $\mathrm{H} 4$ research hypothesis is therefore not val idated.

H5: Professional accountants' self-confidence is in direct correlation with their opinion regarding the main aspects that influence the carrying out of an accounting judgment process.

We have analyzed answers to questions Q36 As a rule, do you consider yourself as being convincing?, Q37 Do you usually admit when you are wrong? as well as Q8. Which are the aspects that you believe to influence the professional accounting judgment when choosing an accounting treatment for economic and/or financial events and transactions? The self-confidence was evaluated by computing average scores ranging from 1 to 5 , a high value of the indicator reflecting a high selfconfidence. These values were used in correlation to the average scores reflecting the answers to question 8, computed as stated previously. The Pearson's correlation coefficient which equals 0.122 reflects a direct but weak correlation between accountants' self-confidence and their opinion regarding the main aspects that influence the carrying out of an accounting judgment process. The value is statistically significant for a 0.05 level of confidence, hence, H5 research hypothesis is validated. 
H6: Professional accountants' self-confidence is in direct correlation with their opinion regarding the need of a theoretical framework of accounting professional judgment.

We have anal yzed answers to questions Q36 As a rule, do you consider yourself as being convincing?, Q37 Do you usually admit when you are wrong? as well as Q11. Do you believe that the accounting professional judgment can be carried out only after all the information regarding the event or economic/financial transaction had been collected and analyzed? Q12. Do you believe that the accounting professional judgment can be carried out only in the presence of an applicable accounting conceptual framework for the accounting standards, regulations and other accounting guide books? Q13. Do you believe that the accounting professional judgment can be carried out only after a proper logical reasoning process? Q14. Do you believe that the accounting professional judgment should be adequately documented? Pearson's correlation coefficient which equals 0.09 reflects a direct but weak correl ation between the accountants' self-confidence and their opinion regarding the need of a theoretical framework of accounting professional judgment The value is statistically significant for a 0.05 level of confidence, hence, $\mathrm{H} 6$ research hypothesis is therefore validated.

\section{Conclusion, limits and further research}

Study and investigate, in many and different ways, judgment and decision making in accounting, nowadays, is of huge interest due to the need of better understanding how a true professional accountant can successfully handle the multitude of challenges that put pressure on him Performance indicators of company, managers expectations, financial reporting framework and standards, time deadlines of various reports, auditors opinion, budgeting policies, accounting options, online business development, and other several factors, exert a tremendous pressure on the performance of professional judgment in accounting and also on decision making. In this context, in order to face gracefully all these challenges, professional accountants should be endowed with personality traits and cognitive abilities such as self-confidence, optimism, clarity in thinking, stress resistance, ability to adapt to changes, ability to withstand risks, uncertainties and vulnerabilities, and so on. Hence, today is more about individual and transversal skills and abilities and less about specialized skills concerning bookkeeping, accounts and preparing the reports.

In this paper through a survey on Romanian professional accountants we have investigated their perception regarding judgment and decision making in accounting, collecting a total of 531 valid responses to our questionnaire The analysis of obtained results showed that most of the investigated accounting professionals considered that a specific professional judgment in accounting is mainly influenced by the responsibility of the accountant in preparing the financial 
statements in line with the economic reality and accordingly to the provisions of the regulatory financial reporting framework and accounting standards. Also, the investigated professionals think that an adequate accounting judgment is best characterized by the following characteristics: "logical, consistent and substantiated".

Further on, exploring a potential statistical difference between accountants, grouped by gender, age, as well as years of practice in what concerns optimism, risk taking and self-confidence, we have conducted a T-test for the difference between the means in each group, and found that there is a statistical significant difference only in what regards the optimism of the accountants, grouped by age. Thus, the younger investigated accountants are more optimistic that the ones over 45.

Our hypotheses test results have shown that there is no statistical correlation between professional accountants' propensity towards optimism and their choice regarding the main aspects that influence the professional accounting judgment, as there is no inverse correlation between accountants' propensity towards risk and their perception regarding the need of theoretical framework of professional accounting judgment. On the other hand, the results shown that there is a correlation between the accountants' propensity towards optimism and their perception regarding the need of a theoretical framework of professional accounting judgment, and between accountants' propensity towards risk and their choice regarding the main aspects that influence the professional accounting judgment Also, professional accountants' self-confidence is in direct correlation with their opinion regarding the main aspects that influence judgment and decision making in accounting and with their opinion regarding the need of a theoretical framework of accounting professional judgment.

The limits of our study are found in the sampling process and survey questions formulation. However, it contributes to enriching judgment and decision making literature by testing the links between several personality traits variables and accounting professional judgment Future works will be oriented towards statistical investigation of different correlations between received answers conceming professional accounting judgment, demographic variables and time deadlines, managers and clients expectations and satisfaction.

\section{Acknowledgements}

This work has been presented at the $12^{\text {th }}$ edition of the International Conference Accounting and Management Information Systems (AMIS 2017) held at the Bucharest University of Economic Studies, on J une 7-8, 2017, under the title of "Accountants are not robots! How professional accounting judgment is affected by individual optimism risk taking and self-confidence". 


\section{R eferences}

Albu, C.N., Albu, N. \& Alexander, D. (2010) “Accounting change in Romania - A historical analysis", paper presented at AFC 2010 Congress, avai lable online at https://www.victoria.ac.nz/sacl/about/events/past-events2/pastconferences/6ahic/publications/6AHIC-27 FINAL paper.pdf, 1-50

Albu, C.N., Albu, N., Faff, R. \& Hodgson, A. (2011a) “Accounting competencies and the changing role of accountants in emerging economies: the case of Romania", Accounting in Europe, vol. 8, issue 2: 155-184

Albu, N., Albu, C.N., Girbina, M.M. \& Sandu, M.I. (2011b) "The implications of corporate social responsibility on the accounting profession: the case of Romania", Amfiteatru Economic, vol. XIII, February 2011, no. 29: 221-234

Barber, B.M. \& Odean, T. (2001) "Boys will be boys: gender, overconfidence and common stock investment", The Quarterly J ournal of Economics, 261-292

Barcellos, L.P., Cardoso, R.L. \& Busanelli de Aquino, A.C. (2016) “An assessment of professional accountants' cognitive reflection ability", Advances in Scientific and Applied Accounting, vol. 9, no. 2: 224-239

Bar-J osef, S. \& Venezia, I. (2014) "An experimental study of overconfidence in accounting numbers predictions", International Journal of Economic Sciences, vol. 3, no. 1: 78-89

Belkaoui, A. (1980) "The interprofessional linguistic communication of accounting concepts: an experiment in sociolinguistics", Journal of Accounting Research, 18(2): 362-374

Bimberg, J.G. (2011) "A proposed framework for behavioral accounting research", Behavioral Accounting Research, vol. 23, no. 1: 1-43

Bogdan, V., Ban, O.I. \& Tara, I.G. (2015a) “Endogenous human variables affecting performance of JDM in accounting. Experimental research on Romanian students", Proceedings of the $14^{\text {th }}$ European Conference on Research Methodology for Business and Management Studies, University of Malta, Valetta, ISBN 978-1-910810-11-8, E-book ISBN 978-1-910810-12-5, 55-62

Bogdan, V., Mester, I.T. \& Popa, D.N. (2015b) "Testing master students perception regarding judgment and decision making in accounting", Annals of University of Oradea, Economic Sciences, Tom XXIV, University of Oradea, ISSN 1222- 569X (printed format), ISSN 1582-5450, 1st issue/] uly 2015: 1339-1347

Bogdan, V., Tara, I.G. \& Ban, O.I. (2016) "Experimental research of economics MA students' perception on the theoretical framework of professional judgment in accounting in connection with individual personality traits", Review of Research and Social Intervention, vol. 55, December issue: 98-111

Brown, G. A., Collins, R. \& Thornton, D.B. (1993) "Professional J udgment and Accounting Standards", Accounting, Organizations and Society, 18 (2): 275-289 
Brown, T.J ., Churchill J r., G.A. \& Peter, J.P. (1993) "Improving the measurement of service quality", J ournal of Retailing, vol. 69, no. 1: 127-39

Chand, P. \& Patel, C. (2011) "Cultural and Noncultural Factors Affecting Judgments of Professional Accountants: A Comparative Study of Australia and Fiji", in P. Chand \& C. Patel (eds.) Achieving Global Convergence of Financial Reporting Standards: Implications from the South Pacific Region (Studies in Managerial and Financial Accounting, Volume 22) Emerald Group Publishing Limited, 105 - 139

Chung, J.O.Y., Cohen J.R. \& Monroe G.S. (2008) "The Effect of Moods on Auditors' Inventory Valuation Decisions", Auditing: A J ournal of Practice \& Theory, vol. 27, no. 2: 137-159

Clor-Proell, S. \& Nelson, M. (2007) "Accounting Standards, Implementation Guidance, and Example-Based Reasoning", Journal of Accounting Research, 45(4): 699

DellaVigna, S. (2009) "Psychology and Economics: Evidence from the Field", J ournal of Economic Literature, 47(2): 315-372

Doupnik, T. \& Richter, M. (2004) "The Impact of Culture on the Interpretation of "In Context" Verbal Probability Expressions", J ournal of International Accounting Research, 3(1): 1-20

Emby, R. \& Gibbins, M. (1988) "Good Judgment in Public Accounting: Quality and J ustification", Contemporary Accounting Research, Spring, 287-313

Frederick, S. (2005) "Cognitive Reflection and Decision Making", Journal of Economic Perspectives, 19(4): 25-42

Gibbins, M. (1984) "Propositions about the Psychology of Professional Judgment in Public Accounting", J ournal of Accounting Research, vol. 22, no. 1: 103125

Gray, S.J. (1988) "Towards a theory of cultural influence on the development of accounting systems internationally", Abacus, A Journal of Accounting, Finance and Business Studies, vol. 24, issue 1: 1-15

Gul, F.A. (1983) "A Note on the Relationship between Age, Experience, Cognitive Styles and Accountants' Decision Confidence", Accounting and Business Research, vol. 14, issue 53: 85-88

Helliar, C.V., Lonie, A.A., Power, D.M. \& Sinclair, C.D. (2002) “Managerial attitudes to risk: a comparison of Scottish chartered accountants and UK managers", J ournal of International Accounting, Auditing and Taxation, vol. 11, issue 2: 165-190

Hofstede, G. (1980) "Culture and Organizations", International Studies of Management \& Organization, vol. 10, issue 4: 15-41

Hronsky, J . J. F. \& Houghton, K.A. (2001) "The Meaning of a Defined Accounting Concept: Regulatory Changes and the Effect on Auditor Decision Making", Accounting, Organizations and Society, 26(2): 123-139

Ifchner, J. \& Zarghamee, H. (2014) "Affect and Overconfidence: A Laboratory Investigation", J ournal of Neuroscience, Psychology and Economics, vol.7, no. 3: $125-150$ 
Istrate, D.M. (2004) Cahle din Transilvania şi Banat de la începuturi până la 1700 [Cahle from Transylvania and Banat from the beginning until 1700], Ed. Accent, Cluj-Napoca

Jones, G.E. \& Abraham A. (2008) “Preparing accountants for today's global business environment: the role of emotional intelligence in accounting education", University of Wollongong, Research Online, 1-16

Kahneman, D. (2011) Thinking, fast and slow, New York: Farrar, Straus and Giroux

Lerner, J.S. \& Keltner, D. (2000) "Beyond valence: Toward a model of emotionspecific influences on judgment and choice" Cognition and emotion. Special issue: Emotion, cognition and decision making, 14: 473-493

Lerner, J.S. \& Keltner, D. (2001) "Fear, anger, and risk", J ournal of Personality and Social Psychology, 81: 146-159

Libby, R. \& Luft, J. (1993) "Determinants of J udgment Performance in Accounting Setting: Ability, Knowledge, Motivation and Environment", Accounting, Organization and Society, 18(5): 425-450

Lin, K.Z., Fraser, I. \& Hatherly, D.J. (2003) "Auditor analytical review judgement: A performance evaluation", British Accounting Review, 35(1): 19-34

Loewenstein, G.F., Rick, S. \& Cohen, J. (2007) "Neuroeconomics", Annual Review of Psychology, 59: 1-26

Lui, S.S., Ngo, H.J. \& Wing-Ngar, Tsang, A. (2001) "Interrole conflict as a predictor of job satisfaction and propensity to leave. A study of professional accountants", J ournal of Managerial Psychology, vol. 16, no. 6: 469-484

Malmendier, U. \& Tate, G. (2005) "CEO overconfidence and corporate investment", J ournal of Finance, 60: 2660-2700

Mapp, K.A. (1937) "Educating Our Students - What Is Our Responsibility?", Canadian Chartered Accountant, October, 255-258

Mason, A. K. \& Gibbins, M. (1991) "Judgment and U.S. Accounting Standards", Accounting Horizons, 5(2): 14-2

Masters, R. \& Deines, D. (2011) “Risk Taking Propensity of Management Accountants: Certified vs Noncertified", The J ournal of Applied Business Research, vol.4, no. 3: 9-14

McKenna, F.P. (1993) “It won't happen to me: Unrealistic optimism or illusion of control?", British J ournal of Psychology, 84: 39-50

Miller, W. (1987) "How CEOs Make Decisions", Industry Week, February, 41-44

Mustata, R.V., Fekete, S., Matis, D. \& Bonaci, C.G. (2011) "Motivating accounting professionals in Romania. Analysis after five decades of Communism ideology and two decades of accounting harmonization", Accounting and Management Information Systems, 10(2): 169-201

Klein, C.T.F. \& Larsen, M.H. (2002) "Perceived control and the optimistic bias: a meta analytic review", Psychology and Health, vol. 17, no. 4: 437-446

Olimid, L. \& Calu, D. A., (2010) "An Explanation of the Change in Accountants' Attitude Towards Flexibility Using the Theory of Reasoned Action", Revista Analele Universității din Oradea, seria ŞtiințeEconomice, Tom XIX 2010, available at SSRN: $h$ ttps://ssm.com/abstract $=2852021$ 
Oyer, P. \& Schafer, S. (2005) "Why do some firms give stock options to all employees? An empirical examination of altemative theories", J ournal of Financial Economics, vol. 76, no. 1: 99-133

Patel, C., (2006) "A comparative study of professional accountants' judgements", Studies in Managerial and Financial Accounting, Elsevier, vol. 15

Patten, D.M., (1990) "The differential perception of accountants to Maccoby's head/heart traits", J ournal of Business Ethics, vol. 9, issue 10: 791-798

Payne, J.W., Bettman, J.R. \& J ohnson, E.J . (1992) "Behavioral decision research: a constructive processing perspective", Annual Review of Psychology, 43: 87-131

Russo, J.E. \& Schoemaker, P.J. (1992) “Managing Overconfidence”, Sloan Management Review, Winter, 7

Shafer, W.E. (2002) "Ethical pressure, organizational-professional conflict, and related work outcomes among management accountants", J ournal of Business Ethics, July, vol. 38, no. 3: 263-275

Siegel, G. (2000) "Skills needed for entry level management accounting positions", Practice analysis, Strategic Finance, 79-80

Slovic, P. (2000) "The Perception of Risk", Sterling, VA, EarthScan

Solomon, I. \& Trotman, T. K. (2003) "Experimental judgment and decision research in auditing: the first 25 years of AOS", Accounting, Organization and Society, 28(4): 395-412

Treadway National Commission on Fraudulent Financial Reporting (1987) "Report of the National Commission on Fraudulent Financial Reporting", available online at http://3197d6d14b5f19f2f440-5e13d29c4c016cf96cbbfd197c 579b45.r81.cf1.rackcdn.com/collection/papers/1980/1987_1001_TreadwayF raudulent.pdf, $10-25$

Trotman, T.K., (1998) "Audit judgment research - Issues addressed, research methods and future directions", Accounting and Finance, 38(2): 115-156

Usurelu, V.I., Marin, Nedelcu, M., Danaila, Andrei A.E. \& Loghin, D. (2010) "Accounting ethics - Responsibility versus Creativity", Annals of the University of Petrosani, Economics, 10(3): 349-356

Weber, E.U. \& J ohnson, E.J . (2009) "Mindful Judgment and Decision Making", Annual Review of Psychology, 60: 53-85

Weisner, M. (2015) "Three Studies Examining the Effects of Psychological Distance on Judgment and Decision Making in Accounting", University of Central Florida, Doctoral Dissertation

Weinstein, N.D. (1980) "Unrealistic optimism about future life events", J ournal of Personality and Social Psychology, 39: 306-320

Weinstein, N.D. \& Klein, W.M. (1996) "Unrealistic optimism present and future", J ournal of Social and Clinical Psychology, 15: 1-8 